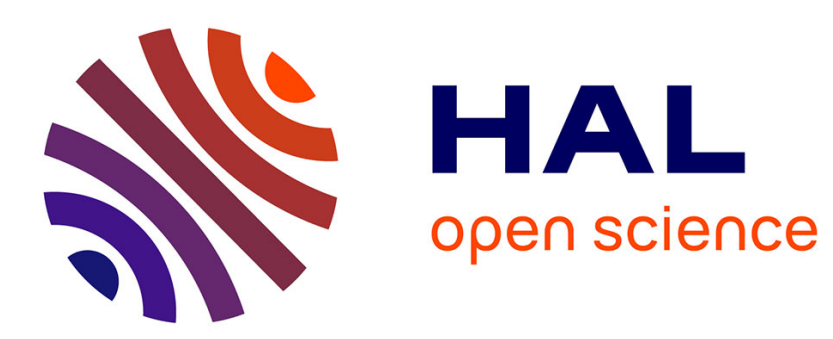

\title{
The Declaration of the Rights of Indigenous Peoples and the World Indigenous Movement
}

\author{
Irène Bellier
}

\section{To cite this version:}

Irène Bellier. The Declaration of the Rights of Indigenous Peoples and the World Indigenous Movement. Griffith Law Review, 2005, 14 (2), pp.227-246. halshs-00425489

\section{HAL Id: halshs-00425489 \\ https://shs.hal.science/halshs-00425489}

Submitted on 21 Oct 2009

HAL is a multi-disciplinary open access archive for the deposit and dissemination of scientific research documents, whether they are published or not. The documents may come from teaching and research institutions in France or abroad, or from public or private research centers.
L'archive ouverte pluridisciplinaire HAL, est destinée au dépôt et à la diffusion de documents scientifiques de niveau recherche, publiés ou non, émanant des établissements d'enseignement et de recherche français ou étrangers, des laboratoires publics ou privés. 
The Declaration of the Rights of Indigenous Peoples and THE WORLD INDIGENOUS MOVEMENT

Irène Bellier*

\begin{abstract}
Over the last decade, under the auspices of the Commission on Human Rights, indigenous peoples have been associated by the United Nations (UN) in the negotiations concerning the Draft Declaration of the Rights of Indigenous Peoples. Even though the whole story started with the mobilisation of Northern, Central and South Amerindian organisations, which remain extremely active, indigenous representatives are now coming from all over the world to participate in the annual sessions. Known to be an aspirational document, equivalent to the Universal Declaration of Human Rights and able to protect indigenous collective rights, the Draft Declaration is to be adopted through the formation of a consensus. Nothing has been adopted yet, and the controversies regarding the language of the Draft Declaration, as well as the oppositions between state and non-state actors, demonstrate that the international identification of a people and the definition of collective human rights remain difficult. However, in the last three years a series of changes concerning the development of indigenous issues have been observed, both in the UN's Working Group on the Draft Declaration (WGDD) and on the national and regional stages where constitutional changes (South America) and a reflection on the definition of indigenous issues (Africa, Asia) are being introduced. Based on participant observation of the process held in the UN, the following article deals with the politics of thisnegotiation and analyses the positions of the different actors involved and their impact on the development of the world indigenous movement.
\end{abstract}

The Draft Declaration of the Rights of Indigenous Peoples aims at finalising an aspirational document to protect the world's indigenous peoples' rights to live according to their own customs, in their traditional lands and territories, situated in states following various forms of colonisation and marginalisation. Ten years after the United Nations (UN) Intersessional Working Group for the Draft Declaration (WGDD) (1994) began its task of improving the text and reconciling the positions between states and indigenous peoples, nothing has been adopted, except for two articles which focus on individual rights. The basis for a consensual language remains extremely unstable, and the definition of collective human rights divides the majority of the states which are party to the negotiations. A few states, as well as indigenous organisations with

Maison de Science de L'Homme, Centre National de la Recherche Scientifique (CNRS) Laboratoire d'anthropologie des institutions et des organisations sociales (LAIOS) CNRS. 
opposing rationales, recently contested the present UN process that does not allow for any progress. However, for a number of indigenous organisations which signed a petition to renew the mandate of the WGDD in April 2005, a momentum has been created that should not be interrupted if indigenous peoples want to have a say in their own development.

The mobilisation started 30 years ago when a massacre of the Yanomami in Brazil stimulated the creation of a human rights organisation focusing on indigenous issues only in Europe (Survival International and the International Working Group for Indigenous Affairs, with their headquarters in London and Copenhagen respectively) and in the United States (Cultural Survival, Cambridge, MA). With the development of international campaigns and the pressure of NGOs, the United Nations, under the auspices of the Commission on Human Rights (CHR), decided to launch a process aiming at identifying the specific discriminations indigenous peoples suffer in the world, in order to set norms and standards appropriate to the defence of extremely vulnerable populations which constitute a significant part of the world's cultural diversity. ${ }^{1}$ The UN system and a family of agencies progressively developed these indigenous issues; the human and ecological realities of indigenous peoples became better known, with their problems attended to locally, when indigenous representatives decided to commit themselves at the UN level. They started participating in the working groups (since 1982), as well as lobbying for the inclusion of indigenous issues on many world agendas, such as sustainable development, cultural diversity, the fight against poverty and intellectual property.

The indigenous peoples succeeded in 2000 in creating the Permanent Forum for Indigenous Issues, which is the first permanent structure for nonstate actors created under the auspices of the UN Economic and Social Council. This places indigenous issues in the mainstream of a variety of UN programs, and gives them greater significance. In parity with the governments who appoint their own experts, eight indigenous experts are being elected for three years by local, national or regional organisations to represent Europe, Asia, Latin America, Central America, North America, Africa and the Pacific. A rotating chair is given every three years to Africa, Asia and South America, due to their larger indigenous populations. In 2002, a special rapporteur for the basic freedoms and human rights of indigenous peoples has been nominated - a sign that indigenous problems need special attention within the human rights domain.

The discussions on the Draft Declaration have developed within this context, with meetings being held annually in Geneva where most of the UN activities regarding the indigenous peoples take place; the Permanent Forum sessions are held at the UN's New York headquarters.

It is difficult to explain why the language formulated by the five international independent experts appointed by the UN Sub-Commission on the Promotion and Protection of Minorities for the Working Group on Indigenous Populations (WGIP) - who worked in close association with

See Morin (2005). 
indigenous peoples' representatives over a nine-year period (1985-94) cannot be accepted by the states who participated in the drafting process. The fact is that it represents a political challenge. The current situation seems to reflect an impossibility for some states - amongst the most powerful - to legitimise the indigenous demands for collective rights as part of human rights instruments.

The present stage of negotiations calls for reflection about two matters. The first concerns the importance of the action taken by non-state representatives to bring the attention of the international community to the specificities of the discrimination that concerns indigenous peoples in the places where they try to survive - in the wake of academic discussions on the new patterns for collective action and the changing configuration of democracy. The second point concerns the capacity to make international human rights instruments evolve into something coherent with the needs of present populations, which are suffering from regular violations of their rights, both as individuals and as belonging to a collective entity. Both matters raise the issue of what states' priorities are for the development of their economies and societies in a global world. They also question the nation(s)-to-state relationship. This paper deals with two crucial questions relating to the Draft Declaration. The first concerns the possibility for the indigenous peoples to be recognised as a people, a question that is considered both for its symbolic aspect (the international recognition) and its political consequences (the right to self-determination). The second concerns the possibility for states to recognise collective rights and to transfer property rights on lands, territories and resources to sectors of the national society. These two key issues constitute the rails the world indigenous movement use to construct and affirm a political capacity. ${ }^{2}$

\section{The Importance of Recognition as a People}

To understand the current UN context of what seems to be a gridlock, it is fruitful to question the founding opposition between states (together with the dominant societies) and indigenous peoples. The definition of indigenous peoples, as taken from the Martinez Cobo Report on the Specific Discriminations Against Indigenous Populations, ${ }^{3}$ underlines the fact that they are:

peoples and nations who present a historical continuity with society prior to the conquest and colonization of their territory and consider themselves as different from the other sectors of society which rule upon these territories or are part of them. They constitute non-dominant sectors of societies and are determined to preserve, protect and transmit to the future generations their ancestral lands and ethnic identity, in accordance with their own cultural systems, legal systems and social institutions.

\footnotetext{
See Bellier and Legros (2001).

E/CN.4/sub 2/1986/87 add 1-4.
} 
See also the 'definition' proposed on the UN website. ${ }^{4}$

Indeed, several elements constitute common ground for identifying different indigenous peoples all over the world, to distinguish the problems confronting them from those facing the national, regional, ethnic or linguistic minorities in the 70 or so countries which do have an indigenous presence. The difference between being acknowledged as 'indigenous peoples/populations', 'ethnic/national minorities', 'scheduled cast and scheduled tribes' and not being recognised at all - and thus being deprived of any kind of status, rights or form of citizenship - is crucial in terms of the destiny of the respective populations. It also affects local communities' opportunities to preserve, protect and transmit their culture, knowledge and lands. Dominant in the indigenous discourse, no matter where the representative has come from, is the wish to transmit the cultural knowledge and the traditional territory (in the sense of a body of learning through which young people learn how to live) to the next generation, with full respect for the elders.

Within this background, where so many different statuses can be observed, the recognition of indigenous peoples as peoples is most controversial. States accept the notion of 'population', consistent with the fact that states are the disciplinary agents of modern life ${ }^{5}$ that control populations to collect taxes, distribute allocations, define the electoral constituencies, and so on. But states are reluctant to admit indigenous communities, systems and authorities to be considered as peoples - given that the marginalisation of these groups forms the basis for states' development as dominant societies and states. There are many different possible definitions of a people, each of which embodies different rights.

Indigenous peoples' representatives defend the idea of a selfidentification as a people: 'I claim to be indigenous and my people recognize me as part of them.' They plead for the recognition to be entitled to their own legal, social and political systems, the meaning and functions of which are shared by the members of the group/people; ${ }^{6}$ they plead to be recognised as

www.unhchr.ch/html/racism/00-indigenousguide.html: 'There are an estimated 300 million indigenous peoples in more than 70 countries worldwide. Indigenous peoples are the inheritors and practitioners of unique cultures and ways of relating to other peoples and to the environment. Indigenous peoples have retained social, cultural, economic and political characteristics that are distinct from those of the dominant societies in which they live. Despite their cultural differences, the various groups of indigenous peoples around the world share common problems related to the protection of their rights as distinct peoples.'

Foucault (1993).

6 Article 1, common to the two covenants, states: '1. All peoples have the right of self-determination. By virtue of that right they freely determine their political status and freely pursue their economic, social and cultural development. 2. All peoples may, for their own ends, freely dispose of their natural wealth and resources without prejudice to any obligations arising out of international economic co-operation, based upon the principle of mutual benefit, and international law. In no case may a people be deprived of its own means of subsistence. 3. The States Parties to the present Covenant, including those having responsibility for the administration of Non-Self-Governing and Trust Territories, 
different from the rest of society by the others, bystates, by local authorities, and so on. They fight for their recognition as a people (unqualified and equal to any other people) on line with the international meaning of the word as proposed by Article 1, common to the two 1966 International Covenants on Civil and Political Rights (ICCPR) and on Economic, Social and Cultural Rights (ICESCR).

Different states usually have varying visions of what constitutes a people as this term is defined by their Constitution. In the French culture, for instance, the Republican meaning of the word acknowledges an abstract unified people without difference of gender, colour, religion, race or ethnic affiliation. ${ }^{7}$ Under such a provision, the French constitutionalists block any political attempt to transfer parts of the national sovereignty to sectors of the people, and therefore deny the possibility of acknowledging the title of 'a people' to a particular minority like the Corsican or the Guyanese indigenous peoples. The Republican state does not recognise national, regional, linguistic or ethnic minorities on the French territory (both on the continent and in overseas departments), even though it admits differences exist within French society it provides some means for training in regional language and supports the cultural and religious developments of a variety of social groups. In other words, minorities and peoples exist in society and may freely develop in private spaces, but they do not enjoy specific rights or constitutional provisions in the political order and public space that are centred on the notion of citizenship - the basic meaning of which refers to the three words 'Freedom, equality, fraternity'. However, since the violence in New Caledonia led to the Noumea Agreement with the Kanak people, this indigenous people living in a French overseas department has been engaged in the process of opening the lid. ${ }^{8}$ At the UN, the French delegates, properly instructed by the Ministry of Foreign Affairs as diplomats usually are, question the notion of 'a people' as does the United States, together with a number of other states - and they

shall promote the realization of the right of self-determination, and shall respect that right, in conformity with the provisions of the Charter of the United Nations.'

7 The 1958 French Constitution, Article 3, states that 'national sovereignty belongs to the people who exerts it through its representatives and the use of referendums. No section of the people, no individual can claim to enforce it alone.' ( $\mathrm{La}$ souveraineté nationale appartient au peuple qui l'exerce par ses représentants et par la voie du référendum. Aucune section du peuple ni aucun individu ne peut s'en attribuer l'exercice.)

$8 \quad$ The Ministry for Overseas Departments states: 'Colonisation injured the Kanak people's dignity that it has been deprived of its identity ... It is necessary to remember these difficult times, to recognize the errors, to restitute the Kanak people its confiscated identity, which means to recognize its sovereignty, shared in a common destiny ...' (la colonisation a porté atteinte à la dignité du peuple kanak qu'elle a privé de son identité [...] Il convient de faire mémoire en ces instants difficiles, de reconnaître les fautes, de restituer au peuple kanak son identité confisquée, ce qui équivaut pour lui à une reconnaissance de sa souveraineté, partagée dans un destin commun. www.diplomatie.gouv.fr/actual/dossiers/ncal.html) 
refuse to have it inserted expressly in the Draft Declaration. Providing an interpretation of the articles which bears upon individual rights, they accept a wording like 'indigenous people and individuals have the right to ...' They understand that some collective rights must be defined, particularly to protect the world's cultural diversity (for example, language, culture, spirituality, customs, practices), but they oppose the formulation of collective human rights.

Claiming to be a people - part of a collective - is clearly an important stance for the individuals, groups and communities who do not recognise themselves in the national project that used to define the nation state. It is a position that is full of political consequences, and it represents an opportunity for indigenous peoples to express their different philosophy of the world, based on social organic solidarities and particular relationship with the environment. ${ }^{9}$ It opposes the view developed by the states which primordially defend the principle of territorial integrity - and which, on this basis, are reluctant to apply the principle of self-determination to sectors of their own societies. They stick to the internationally defined human rights principles, based on individualism and the differential treatment of the person who can be detached from group and family solidarities and so be involved into (and protected from) industrial societies' developments. Through the voices of their representatives in the UN forums, indigenous peoples do not oppose individual human rights mechanisms, but consider that these do not protect them - and the list of violations presented to the UN Human Rights Committee in Geneva each year is seemingly endless.

The human rights issue is linked to an ideological position and political manipulations. Generalisation is inappropriate to clear the political distinctions that cross the world indigenous movement and the states, but the observation of the two working groups in Geneva allows for the identification of some headlines. On the one hand, indigenous peoples oppose capitalism - the dominant system on which modern societies are developing without any alternative model since the fall of the Soviet regime. They especially oppose the fact that capitalism is based on private property and the promotion of individualist principles. A criticism of capital is re-emerging in different places and periods, currently through the anti-globalisation movement, in a way that is sympathetic to indigenous battles and the ideas that indigenous peoples have about sustaining development. Globally, it contributes to a kind of acceptance of the desire to foster a bigger harmony with 'Mother Earth' - a mythic character that indigenous peoples from all continents have adopted to show to the rest of the world the specificity of their relationship with their lands and territory, both material and spiritual. These claims sustain a relative mobilisation for defining collective rights to protect indigenous peoples as cultural entities in a process that leads toward their political recognition as

\footnotetext{
Bellier (2004).
} 
peoples, since most of them never agreed to become subalterns or subordinated. ${ }^{10}$

On the other hand, the states - especially the United States and the European countries - recall that history cannot be obliterated. Even though the marginalisation of aboriginal populations has unfortunately occurred in all the continents on the wake of colonisation, these states remind us that a system had to be developed and adopted by the international community for protecting individuals against discrimination based on ethnic belonging — especially after the Holocaust. That leads some states to contest the notion of collective human rights (the Anglo-Saxon countries) and push them to protect individuals from what they perceive as leading to communitarianism and fragmentation (the Francophone countries). States are suspicious of the resurgence of dividing lines (and massacres) based on nationalism, religion and ethnicity, and therefore refer to the historical reason for constructing the human rights system, implicitly accusing the indigenous peoples of being against that system and therefore capable of 'barbarianism'. Evidently, a world of prejudice is involved in the opposition of states and dominant societies to indigenous populations in most areas of the world. The term 'civilisation' is used by conquerors to link the idea of the 'other' with concepts like 'barbarian' or 'savage'.

The point is not to withdraw any instrument from a positive evolution of the international system to protect individuals' and communities' human rights. However, states' reasons diverge from indigenous interests. There are many states inclined to attribute existing violence to indigenous peoples without considering either the state's responsibilities in these domains or the reasons for isolated peoples needing to escape the world of politics where they have no place in order to join the way of rebellion. While the last decade of the twentieth century saw some progress in the organisation of the human rights dialogue, with the end of the Cold War, the beginning of the twenty-first century is showing a different tone. After September 11, 2001 and the implementation of anti-terrorist policies in the United States, Europe and the rest of the world, many indigenous organisations are now considered part of 'terrorist organisations' by national authorities, as it is the case in Chile and Indonesia. At the UN, indigenous representatives denounce a radicalisation of the oppositions between states or local authorities and indigenous populations, especially when indigenous peoples intend to protect their territories from neocolonial occupation and the exploitation of their resources by multinational companies. In that domain, indigenous peoples would like the state authorities, multinational companies and global financial institutions to respect the concept of 'free and prior informed consent', and also consult them on 'benefitsharing'.

10 The WGIP commissioned two important studies, on 'The Permanent Sovereignty Over Natural Resources', achieved by Ms Daez, second president of the WGIP E/CN.4/Sub.4/2003/20, and on 'Treaties, Agreement and Other Forms of Constructive Arrangements', achieved by M Martinez, third president of the same group (E/CN.4/Sub.2/1999/20). 
The political context is not stabilised, and given this background it remains important to document and analyse the changes taking place. The indigenous peoples' commitment to becoming true controllers of their destiny should not be understood as necessarily leading to a conflicting state of the world or as stimulating reactionary conservative supports (as suggested by Kuper). ${ }^{11}$ Like most social movements, indigenous peoples and organisations supported by both Marxists and the churches are crossed by ideological standpoints. The debate between armed or peaceful routes to achieving the objective of self-determination has been replaced by discussions regarding the legal movement, the interest and efficiency of mobilising the UN, the politicisation of local levels, and the organisation of civil society (with the creation of NGOs). In that context, the status of the individual as compared to collective rights is being discussed, especially by women, ${ }^{12}$ who intend to improve their relative position whenever they consider themselves to be marginalized. This, for instance, is the case with the Native Women Association in Canada.

To progress the debate among state and indigenous organisations, there is a need to think in depth of the articulation of the two categories of individual and collective human rights, as Saganash and Joffe suggest. ${ }^{13}$ For them:

It is widely recognized that Indigenous rights are predominantly collective in nature. This is profoundly reflected in the cultures, identities, worldviews, and legal systems of Indigenous peoples and nations. Indigenous individuals often exercise rights that flow from these collective rights. Therefore, protection of and respect for collective rights is also a vital factor for the enjoyment of basic rights by Indigenous individuals. ${ }^{14}$

But as Western societies define different principles in varying ways, the question remains as to how to clear the political and historical backgrounds that lead states to stick to a conservative position such as the one described by Saganash and Joffe in their criticism of the United Kingdom. Saganash and Joffe quote the views of the United Kingdom:

With the exception of the right to self-determination (which forms article one of the two international covenants on human rights), we [the United Kingdom] do not accept the concept of collective rights ... Of course certain rights belonging to individuals can often be exercised

\section{Kuper (2003).}

12 The Permanent Forum on Indigenous Issues held its $3^{\text {rd }}$ session in New York in 2004, on the issue of women: see report E/C.19/2004/23

13 Saganash and Joffe (2005), p 15.

14 Saganash and Joffe (2005), p 12; Conceptual Framework Paper (2nd draft) by the Working Group on the Rights of Indigenous Peoples/Communities in Africa of the African Commission on Human and Peoples' Rights, 20 December 2002, p 9: 'The indigenous rights are clearly collective rights, even though they also recognize the foundation of individual human rights.' 
collectively through, for example, freedom of association, freedom of religion or through a collective title to property. ${ }^{15}$

Ex-colonial states do have to deal with the legality and regime of treaties they signed with aboriginal peoples (wherever they did so, and often where they did not), and they face difficulties in interpreting these historical patterns in the human rights framework.

As for the treaties in the $18^{\text {th }}$ and $19^{\text {th }}$ centuries, the Foreign Office insists that they have no relevance to international human rights law, which began with the 1948 Universal Declaration of Human Rights. ${ }^{16}$

However, it is under the auspices of the Commission on Human Rights that indigenous peoples have found support from the international community as the most vulnerable peoples, being under the threat of extinction. A new generation of human rights instruments is to be designed to respond to the variety of menaces today and to the situations in which indigenous peoples are currently engaged.

The time has come for clarification. There are very few uncontacted peoples who live according to their own traditions and customs on their ancestral lands, and who claim to be respected fully. Due to the colonisation and decolonisation processes, and the need to fight against poverty, those peoples who have had to change their way of life, who have lost their language, and whose members have been forced to migrate to the cities or to other countries to get some income, are in the vast majority. But a number of them are determined not only to protect their cultures but also to promote them, even if it is through a complete reconstruction of what their cultures used to be. Indigenous peoples are not the icons that the media fixed in time, thanks to the ethnologists who carefully described their small worlds and defined borders of identity. They are not the 'savages' whose humanity could continue to be discussed as it was from the sixteenth to the nineteenth centuries, but they still suffer from racial discrimination. Nowadays, democratic states must adapt their legal and constitutional systems to the variety of populations who live in their territory, and a real effort needs to be made to respect various populations' wishes to develop cross-border relationships and keep their people united. ${ }^{17}$ The challenge today is to imagine (in order to solve by anticipation) the potential conflicts that may emerge from the fact that indigenous communities, societies and peoples are both determined to preserve their traditional systems and to be active in modern developments. The process of differentiation among indigenous peoples that started a long time ago cannot be solved by the sole declaration that they form a people (the activist viewpoint), or by the denial of their specificities due to their collective identity (the states' attitude).

$15 \quad$ Saganash and Joffe (2005), p 14; United Kingdom (2004), p 212.

16 See Owen Bowcott, 'A Tribal Quest', The Guardian, 15 December 2004, Section $\mathrm{G} 2, \mathrm{p} 13$.

17 See Morin and Santana (2002). 


\section{What is the text under discussion?}

Since 1982, WGIP has served as a forum for indigenous peoples to address the world, and as an expert group in charge of setting new norms and standards on the different items it places on its agenda (development, education, human rights, conflicts, protection of traditional knowledge and intellectual property, etc.). For all indigenous representatives, the basis for the discussion is the Draft Declaration, as it has been written by the UN experts - that is, members of the WGIP - in a nine-year process involving the active participation of numerous states and indigenous organisations. However, according to interviews with the French delegates, 'for the States, there is no precedent that a UN declaration be adopted without considering the changes we want to introduce'. This is why, in 1994, the Commission on Human Rights recommended the formation of a special working group to negotiate the draft, with a mandate to consensually accept a text to be presented to the Commission on Human Rights for adoption before the end of the Indigenous Peoples' Decade (1995-2005).

Every time indigenous leaders suspect the states of being about to introduce major changes, the leaders take care to state that the discussion is to develop the Draft Declaration as it was adopted in 1994 by the UN SubCommission on the Promotion and Protection of Minorities. ${ }^{18}$ Together with their refusal to accept the consequent modifications, some states want to introduce what indigenous peoples call 'the emptying activity of the meaning and content of the declaration' - the 'no change position' (supported by the indigenous peoples and some states) led to a blockage. After ten fruitless years of being confronted by the fear that emptiness causes in the institutional world, the General Assembly decided to call for another decade (2005-2015) to encourage the states' commitment to improve their relationship and dialogue with indigenous peoples. The Commission on Human Rights decided to renew the mandate of the WGDD for a year, though this extension was limited to avoid the multiplication of delaying measures.

Yet political conditions and indigenous attitudes have slowly changed during the decade. After several manoevres at the initiative of the Scandinavian and Baltic states, supported by New Zealand, and after some discussions with the Sami council, an alternate text ('CRP1' in UN jargon) has been circulated, together with a table listing the differences from the original draft and outlining, in a third column, the changes that are introduced. This text was used in the 2004 session by the president-rapporteur as a basis for leading the discussions. A close examination reveals that it intends to introduce the changes desired by the most concerned powerful states, such as the United States, France, the United Kingdom, Canada and Australia, with an intention of not radically opposing the indigenous views, but rather proposing a coherent language so as to capture the impact of any alternative language as proposed in the previous sessions - on the equilibrium of the whole Draft Declaration. This attitude has been criticised by a number of indigenous organisations, which are under the impression that the president is paying more

18 Morin (1992) 
attention to the states which want to introduce radical changes in the declaration than to those states and indigenous organisations which want to preserve it as it is. As a result, the president-rapporteur (a Peruvian diplomat), whose capacity to build a consensus has not been proved, is being criticised by both states and indigenous parties. However, the WGDD mandate was renewed during the $61^{\text {st }}$ session of the Commission on Human Rights (in April 2005) and GRULAC, the Group of Latin American and Caribbean Countries which is in charge of presiding over this particular working group, is going to support him for yet another term. The present situation opens a new political landscape where the initial antagonism between indigenous peoples and states is being replaced by the division of the two blocks, from which several strategies can be fomented.

\section{Radical Oppositions on Core Issues: Self-determination, Land, Territory and Resources}

Throughout seven sessions, the president-rapporteur of the WGDD based the discussions between states and indigenous peoples' organisations on the less controversial articles, in order to build the consensus needed for successfully concluding the negotiation. As a result, over ten years of negotiations, only two articles out of 45 have been adopted that focus on individual human rights (Articles 5 and 43).

In the $8^{\text {th }}, 9^{\text {th }}$ and $10^{\text {th }}$ sessions, the president-rapporteur decided that it was time to examine the whole Draft Declaration in order to try to approximate the positions formulated by the states and indigenous representatives on the most controversial series of articles regarding self-determination (Articles 3, 31, 36) and land, territory and resources (Articles 25-30). The discussions on these two sets of articles clearly revealed the oppositions between some states and most indigenous representatives. The centrality in the Draft Declaration of self-determination, and the provisions concerning land and territory in relation to the corpus of collective rights that were demanded, appeared very clearly, as did the need to clarify the international understanding of the articles discussed to push the states to evolve politically — a task that indigenous and nonindigenous legal advisers, law teachers and consultants take very seriously, especially for lobbying the states.

For the moment, the states are limiting the emergence of new international obligations for distinct reasons, responding on the one hand to the constitutional provisions they have adopted domestically, and on the other to the way they agree (or not) on the definition of human rights mechanisms, giving priority to the defence of individuals and the promotion of equality in society. A few states' contrasting positions can be cited. The Latin American countries do not want to see an international declaration to fix recommendations or obligations below the standards they accepted when they adapted their constitutions to the recognition of a multicultural, multinational,

19 Article 5 states: 'Every indigenous individual has the right to a nationality'; Article 43 states: 'All the rights and freedoms recognized herein are equally guaranteed to male and female indigenous individuals.' 
multilingual society (Colombia 1991, Bolivia 1994, Brazil 1994, Ecuador 1998, Venezuela 1999, Mexico 2002). The Security Council members France, the United States, the United Kingdom, Russia and China - do not accept new obligations emerging from the international community, and resist the new forms of transnational solidarities that would force them to adjust their constitutional provisions. The Scandinavian states, which have already transferred partial sovereignty to the Sami people organised through a Sami transnational parliament, intend to pragmatically find the means to reconcile the states and indigenous peoples' opposition, as well as the differentiated states' viewpoints. ${ }^{20}$

\section{The Positions of the Partners/Opponents in the Negotiations}

For an outsider who observed the negotiations over five years, the project of a Declaration on the Rights of Indigenous Peoples seems to result from a collective action where indigenous organisations, supported by human rights organisations and civil society, raised the interest of the international community, stimulating the will to change a model of relationships with dominant states and societies that are based on absolute inequality, denial of human rights and unequal forms of citizenships. For the insider, the scene reveals the existence of an opposition, as the states have been engaged in this endeavour by the mobilisations of the international civil society rather than by their own will, when indigenous organisations are actively searching for other means to solve their situations than those provided by their respective countries. Some mistrust emerges from this contrasted political background, even though the actors have to engage themselves authentically for the negotiation to be achieved successfully. In the frame of globalisation studies, many studies have been devoted to international governance and the multilateral organisations since World War II, but we know very little about the mechanism through which a trust system could develop at the global level.

Regarding indigenous issues, one of the problems is the fact that the movement, which started from the American continent, has progressively generalised to include Europe, Africa and Asia. Such a world expansion, which reveals the similarity of indigenous marginalisation on all the continents, has an impact on the possible definition of universal provisions, as the multiplication of the partners - including both states and indigenous representatives - dramatically increases the level of complexity. Different political structures and cultures coexist and lead to dialogue at the same time as geo-political strategies are formed on which alliances are based, and the states' interests may strongly diverge from those of the indigenous peoples.

For 30 years, the indigenous movement has consolidated its position and built its political authority on its capacity to foster unity. The UN and different international mechanisms, including the establishment of a voluntary fund to financially support the participation of indigenous representatives, have facilitated this. But the most important thing has been the indigenous leaders' own capacity to encourage and channel the participation to the WGIP, to

$20 \quad$ See Bellier (2003). 
transmit to the younger generations the know-how regarding the way to talk in formal situations, to address the president, to dress and be proud of being indigenous, without falling into the folklore to which Western societies usually reduce the difference of cultures. Over the last three decades, the movement that started in the Americas ${ }^{21}$ has been capable of opening itself, welcoming participation by indigenous peoples from Africa, Asia, Russia and elsewhere, to make visible the commonality of their interests, realising through verbal exchanges, direct meetings, and web networking that their situations are very similar, despite the huge differences that exist between peoples, regions, political systems and the ruling majorities.

The activation of the Caucus system - inherited from North American First Nations practices - where indigenous representatives meet every day, before or after the informal and formal sessions, to forge a common position, has been extremely positive. But with the widening of the movement, and given the growing complexity of the topics discussed in different UN institutions (WGIP, WGDD, Permanent Forum on Indigenous Issues, WIPO, UNESCO, the Convention of Biological Diversity Committee of Parties, etc), there has been a need to strengthen the modalities of discussions, leading to the multiplication of regional (North America, South America, Pacific, Arctic, Africa, Asia) and thematic (women, conflict, environment, etc) caucuses under the global indigenous caucus that still represents the indigenous voice. Confronted with the necessity of clearing the positions, both regionally and thematically, at the same time as discussions evolve in the plenary sessions, indigenous representatives face the problem of an impossible ubiquity in terms of their participation in the world institutions. How can they attend simultaneous events (including caucuses, press conferences, meetings with the states' representatives, plenary sessions, and so on) at the UN and in the capital with limited human and financial resources?

As a result, an indigenous international elite has emerged, composed of the delegates and leaders who involve themselves more in the UN processes. They succeed in introducing the indigenous voice wherever they can, but they are at the risk of progressively losing the strength of a unity forged after lengthy discussions. For instance, given the blocked discussions in WGDD, some organisations have lost their patience and confidence that the UN mechanisms will have a real impact on making the situation evolve politically. They circulate letters and petitions to get support, and in so doing show indigenous divisions that bring confusion into the states, especially among these which want to be constructive but do not know which are the right interlocutors to approach. This has been obvious in the last WGDD session and the preparation of the $61^{\text {st }}$ Commission on Human Rights.

A number of American and Pacific indigenous organisations, led by the International Indian Treaty Council, called for a recess in the process so that an evaluation could be made in order to find the best possible way to solve the issue. As the letter sent on 15 March 2005 to the President of the Commission on Human Rights states:

${ }^{21} \quad$ See Bellier (2005); Morin (2005). 
in order to take effective steps that would make the chances of success much greater ... This recess will provide the Commission on Human Rights, beginning at this session, with the opportunity to establish, in full consultation with Indigenous Peoples, a new process which would include effective and viable mechanisms for the voices of the great numbers of Indigenous Peoples from around the world that are affected by these discussions to be heard.

But nobody really knows how this could be done, or who would do the assessment. In response, a number of world indigenous organisations, informed on the one hand by the Tebtebba Foundation (Philippines) and the Sami Council (Scandinavia), and on the other by the Inuit Circumpolar Conference (ICC) and the Grand Council of the Crees (GCC, Canada), signed an online petition calling for the prolongation of the mandate in order to maintain the momentum that has been won through participation in UN mechanisms, and to maintain the pressure on the states for them to adjust their negotiating positions to the need to adopt a declaration. In particular, these organisations are contesting the process followed and find it counterproductive. The letter written by ICC and GCC observes:
An essential priority we have as Indigenous peoples is to maintain unity and solidarity within the Indigenous Caucus - or at least among an overwhelming majority. Therefore, it is highly divisive for the initiators of the March 15, 2005 letter to now propose a strategy that runs counter to what Indigenous peoples within and outside the Caucus are committed to, with no opportunity for timely discussion.

Eventually, Canada introduced a resolution to renew the mandate of WGDD, for the Draft Declaration to be concluded as soon as possible, and before the $62^{\text {nd }}$ CHR. Along with Finland, Guatemala and Mexico, it did not support a US amendment intended to limit the next session to ten days, hence introducing an ultimatum to WGDD. On the side of the states also, homogeneity cannot be detected.

Indeed, there are many divisions between the three categories of states. One category is composed of the 'recalcitrant/obstructive' states (so labelled by many indigenous organisations), which include Australia, France, New Zealand, the United Kingdom, the United States and Japan. Even though different positions can be observed on particular items, they are not inclined to consider indigenous peoples as autonomous peoples, and periodically demand a precise definition of who is going to be concerned by the Draft Declaration. They wish to circumscribe the international obligations of the states to promote national sovereignty and territorial integrity. They prefer to endorse and protect individual human rights, but favour the concept of freedom instead of rights. Therefore, they introduce an element of conditionality for interpreting the principle of self-determination, with a difference between internal selfdetermination and external self-determination. In response to the US declination of internal self-determination, the French state (via the French delegate) proposes to introduce the notion of 'free administration' that is a 
possibility under the legal regime of 'association'. To sum up several negotiating positions in brief terms, these states promote a liberal view of the land issue, acknowledging the existence of a spiritual link with 'Mother Earth' - the generic entity symbolizing the natural relationship of a people to a particular place - and they accept the idea that indigenous peoples have a particular knowledge to be recognised for managing environmental issues. But they do not answer the questions of how to provide the right means to protect land and territories, or how to give indigenous communities collective property rights on the soil and sub-soil resources. They accept the notion of traditional customs and laws, but not that of an indigenous legal system, and they prefer national courts to be charged with regulating the conflicts. Intending to protect the rights of the third parties before conceding indigenous rights, they prefer a system of financial compensation to legal restitution of the indigenous lands and territory. For a long time, Canada has been associated with this group of recalcitrant states, and it is certainly due to indigenous lobbying that a political will to progress on the discussion on self-determination and land rights seems to emerge. Government changes affect the development of good relations with indigenous peoples.

The second category of states is composed of the so-called 'friendly states', who regard it as a priority to adopt the Draft Declaration. This category includes two approaches, one associated with the states which want to support the Draft Declaration as it has been adopted by the Sub-Commission, and one associated with states which want to introduce what they call 'positive changes'. The first approach reflects the GRULAC position, including some states which support the indigenous side and want to be seen to be active on this line, like Mexico and Guatemala, and the states which keep their distance, such as Brazil, Chili and Colombia - an attitude that reflects the differential impact of indigenous peoples in political decisions according to their demographic weight. Among GRULAC, the states that adopted new constitutions during the 1990s in favour of the cultural diversity and the importance of indigenous roots to the national identity have progressively affirmed their voice. They do not want to see international provisions undermining the compromise passed at the national levels. They use the expression 'indigenous peoples'; they admit the existence of indigenous territories and legal systems; and they do not question the possible emergence of collective rights, even though they do not foster their implementation at the regional, national and local levels. Together with North America, they are engaged in the Organization of American States' declaration for the rights of indigenous peoples, Cuba being excluded from the OAS but participating to the UN.

The second group of 'friendly states' defends a form of alternate integrated language to force the renegotiation of the Draft Declaration and oblige the recalcitrant states to concessions, as well as to force the indigenous organisations to quit the 'no change position'. Among these states, led by a group of Scandinavian and Baltic countries, there may exist differences according to political regime, but the fact is that some of them - like Norway, Denmark, Finland and Sweden - are already engaged in negotiation and 
political agreements with the Sami people, and they want to use their capacity to develop a positive dialogue in the region to enforce changes in the Draft Declaration in order to make it acceptable, at least to a majority of the parties, if not to all of them. Due to its changing majority in government, New Zealand has recently joined that group, quitting the recalcitrant states group with which it was associated for years. Together, they want to introduce a clarification of the provisions with regard to the objectives, bringing light to the individual or collective characteristic of a particular right and specifying the idea that indigenous peoples do not need a special right but rather a general one. They are inclined to develop consistency with international human rights instruments, and distinguish the rights of indigenous peoples and the obligations of the states.

The third group includes the states that I consider to be 'indifferent but not neutral', for whom indigenous issues are potentially explosive and kept under control by a denial of recognition. It means essentially African and Asian states which are not attending the WGDD sessions, even though their name is shown on the table. This sign of indifference may be due to a lack of human resources to attend all UN meetings, and/or indigenous issues may not be a priority for the world's sake. But since these states attend the Human Rights Council, and can therefore use their voting rights to block a declaration they would not have discussed in WGDD, this selective attendance is a sign that they are not neutral. Indigenous peoples' representatives, especially those from Asia and Africa, regularly complain of the missing link with their respective country delegates, since they cannot use the opportunity to meet them at the UN to clear their views and try to solve their many problems - as can their 'brothers and sisters' (a terminology they use among themselves) with the American states. It is a sign of their political maturity that lobbying has become an important occupation for many indigenous delegates. When they cannot meet their states' diplomats in the UN session, they must look to meeting them wherever they are.

\section{Shifting Positions: Potential for Adoption or Rupture}

For an anthropologist whose methodology is based on participant observation, it is extremely difficult to foresee the future; however, the momentum that has occurred in the indigenous movement over the last decades is in itself an indicator of how things can develop.

As mentioned already, two years ago, negotiations were accelerated to have the Draft Declaration adopted before the end of the first decade (2005). As nothing has been adopted on time, a second decade called 'Partnership in Action' has now been declared for the indigenous peoples, with the intention of transforming words into actions. The perception that an effort must be made by the states seems to be shared, and they often reassure the indigenous peoples' representatives about their good intentions. But this seems largely rhetorical, at least where it concerns the Draft Declaration. Making an effort to conclude the negotiations does not indicate who is going to make the main compromise or what it will be based upon. Some discouragement can be seen on indigenous sides when states keep repeating the same reservations they 
have expressed since the beginning, without considering the changes that have been introduced during the last decade in favour of the indigenous voice through other platforms of the international system.

Contrasting with the states' fragmented knowledge, as demonstrated by the diplomats who act under instructions of their governments, indigenous representatives retain strong memories of any progress achieved in the world legal organisations regarding their specificity. This is due to the fact that they engage themselves directly in any world discussion of interest for them, and have taken to circulating information and sending reports to each other so that a cumulative capacity can be forged. They bring into the negotiations on the Draft Declaration language coming from other legal or semi-legal sources such as, for instance, the language of the only international instrument that is applicable to Indigenous and Tribal peoples (the ILO Convention 169) and the wording of the provisions concerning indigenous peoples in other Conventions (such as the Convention on Biodiversity or the Convention to Eliminate Racism and Discrimination). Their arguments also refer to semantic evolutions that figure in the world summit declarations on the earth (Rio de Janeiro 1992, Johannesburg 2002), on water (from Stockholm to Kyoto 1972-2003), on the information society (Geneva 2003, Tunis 2005), and so on. Given the states' lack of memory and incapacity to relate the formulation of new norms to other consequences, indigenous representatives try to work consistently to remind states that international norms and standards have to be adapted to the changes in global life, economy and governance. In contrast, the states seem to stick to their domestic issues, and more often than not express their feeling that the 'no change position' adopted by the majority of indigenous organisations does not allow them to move towards a 'positive' rewriting of the Draft Declaration 'positive' in their mind meaning less favourable to indigenous peoples or to particular groups.

Now the situation is such that the indigenous movement, which takes its strength from the cohesion its organisations present in front of the states, has to work out the modalities to reconcile the leaders who despair of getting any consensus with the states in a reasonable period, with those willing to defend the core of the Draft Declaration: self-determination, land rights and control over the resources. They are confronted with deciding among themselves what could be the right strategy to win a declaration without losing the fundamental rights they claim. In the UN's terminology - as, for instance, formulated by Mexico in the $61^{\text {st }}$ CHR - the necessity is to 'bring positions as close as possible'. This country proposed (as others did in former years on other issues) to hold a workshop 'to build bridges of dialogue for new approaches to the toughest and most problematic issues contained in the draft declaration'. This country may be thinking in terms of building bridges between states and indigenous organisations. However, it might also be required to help indigenous organisations to solve their differences in approach through ad hoc meetings, separated from the negotiating sessions which capture their attention, and the rhythm of which, provided by the agenda, does not allow time enough to discuss the collective strategy. The weekend which is usually devoted to that purpose, before any formal session takes place in Geneva 
(CHR, WGIP, WGDD) or in New York (Permanent Forum on Indigenous Issues), and which is supported by the World Council of Churches that is quite active among the IPs, is not sufficient to clarify the issues at stake, to advance a coordinated indigenous voice in front of the states' strategies to divide the movement. But to organise extra sessions, financial means are required to bring together people from all the continents, provide them with translation, and to give them time and support to clear their respective views. The support given by a technical organisation like the Indigenous Peoples' Center for Documentation, Research and Information (DoCip) and several human rights organisations needs to be supplemented by states' contributions - however, very few of these have been forthcoming.

\section{Conclusion}

As compared to 30 years ago, the situation has changed for indigenous peoples, and some states among those most concerned by the problem have developed a system of dialogue with indigenous organisations in an unprecedented fashion (like Canada, Norway, Denmark and Guatemala). This is the fruit of the capacity shown by the indigenous organisations to send responsible representatives, trained in national and international law, experienced in participating to the UN meetings and international settings, and capable of expressing themselves in several languages, to talk with the World Bank and to use all kinds of support, including support from the churches.

But all the regions of the world and all the indigenous peoples are not capable of doing this. Most of them are in the process of building their international political capacity, and participation in UN meetings where concrete exchanges of know-how can take place is a key factor. For instance, compared with their American fellows, African indigenous representatives are just beginning to work at an international level, without having enjoyed all the existing possibilities to understand the international human rights developments in which they have not yet been trained. Like many other indigenous peoples, they are also confronted with the difficulties posed by multilingualism and the use of a dominant language. Francophone indigenous peoples are lost in the international world, which uses English as a medium for communication - even though French is acknowledged (like Arabic, Chinese, English, Russian and Spanish) as a UN official language.

In global terms, the linguistic international background does not fit comfortably with indigenous capacities, given that indigenous mother tongues are never used for declarations, and indigenous peoples are obliged to express themselves in the official language of their country and in one of the official languages of the UN. Those of them who had been - willingly or not trained in English-speaking schools have a relative advantage compared with those who have only attended French schools. That is also due to the number of French indigenous speakers who, until recently (when African indigenous peoples started to move), were in an absolute minority when it came to participating in UN negotiations as compared with Spanish- and Englishspeaking peoples. The same is true for the Arabic and Chinese speakers, who remain marginal for several reasons, among them the fact that most of the 
states which represent these languages do not recognise their indigenous peoples or do not allow their 'national minorities' to attend the UN sessions. The situation is a little different for the Russian speakers, who have been able to attend such meetings since 1991, but who do not constitute a large group of people.

Notwithstanding these difficulties, indigenous leaders and representatives from all the continents manage to get funded by the UN Voluntary Fund. They succeed in learning a few words of English, to obtain support from their indigenous fellows and, like others, involve themselves completely in ' $U N$ business'. The UN's Office of the High Commissioner for Human Rights and the European Commission encourage their involvement, with different programs being tailored for them. Such a process, which is progressing slowly, through the identification of the leaders and the inclusion of individuals as representatives of larger groups and communities, is not uncontroversial, as it questions the representativeness of the states as interlocutors; however, it seems to be adapted to the ways indigenous peoples select their representatives. Nevertheless, to avoid a growing gap between the indigenous elites (sometimes expatriated) and the people within the communities, the UN and the support organisations who finance indigenous peoples' training now pay more attention to the means of ensuring feedback occurs at the local levels in order to limit the progressive isolation of the newly trained leaders.

The juncture with the academic world is demonstrated by the many congresses, symposia and conference where indigenous peoples now participate along with researchers and academics. The rise of the internet has enabled the circulation of different information, the new media being equally used by the activists who post their declarations and by the researchers who consult indigenous people, as well as the institutional and support organisations' websites. Raising awareness among the political class is still to occur in a number of countries (such as France), where indigenous issues are not considered a priority. Deprived of visibility within their own society, indigenous peoples are barely able to be associated to state delegations, and their representation in liberal democracies remains problematic.

The fact is that concentrating on the establishment of international standards has a double effect on the indigenous movement. On the one hand, it creates a group of indigenous experts 22 who know what the international systems are, understand how epistemic communities are forged, and also realise the need to specialise in sectional issues such as intellectual property, the environment, the World Bank programs, and so on, and to work on communication strategy. The relationship between these leaders and those acting within individual countries still requires a better understanding, since the Western system of political representation does not function there. But this

22 The states (eight) and indigenous (eight) members of the Permanent Forum on Indigenous Issues are called 'experts'; the same title is given to the five (nonindigenous) members of the UN's WGIP who are appointed by the SubCommittee for the Promotion and Protection of Minorities, being selected to represent the world's regions (Africa, America, Asia, Western and Eastern Europe). 
movement is inscribed on to the pattern of an evolution of the global system that does not seem to be questioned. From the indigenous viewpoint, even though a sudden change would be welcome, standard-setting takes time, and what is important is to be involved as partners in the negotiation to gain credibility, legitimacy and strength. On the other hand, the first necessity is to bring changes in the places where indigenous peoples and communities are living, and sometimes dying. And it is extremely difficult to foster positive changes for improving their life conditions without an appropriate international instrument. The Draft Declaration would be the first step towards establishing a more legally binding instrument, such as a convention.

The fact is that local temporalities are not like global ones. The 'indigenous camp' expresses a sense of emergency that states do not seem to incorporate in their agendas. States are not ready to engage in the writing of a convention. This explains why states have slowed down the discussions on the Draft Declaration, and why a number of indigenous organisations do not believe in the political process. They call upon the UN to accelerate the process, otherwise there will be no more indigenous peoples left to give rights to.

\section{References}

Irène Bellier (2003) ‘Dernières nouvelles du Groupe de travail sur le projet de déclaration des droits des peoples autochtones à l'ONU' XXXIII Recherches Amérindiennes au Québec 93.

Irène Bellier (2004) 'Regards autochtones sur la mondialisation', 74 Courrier de la planète 56.

Irène Bellier (2005) «Le projet de Déclaration des droits des peuples autochtones et les États américains: avancées et clivages», in C Gros et al, Etre indien dans les Amériques aujourd'hui, Institut des Amériques.

Irène Bellier and Dominique Legros (2001) «Mondialisation et redéploiement des pratiques politiques amérindiennes: esquisses théoriques» XXXI Recherches Amérindiennes au Québec 3.

Michel Foucault (1993) Surveiller et punir, Gallimard.

Adam Kuper (2003) 'The Return of the Native' 44 Current Anthropology 389.

José Martinez Cobo (1986) Report on Discriminations Against Indigenous Populations, E/CN.4/ sub 2/1986/87 add 1-4, United Nations

Morin (1992) «Vers une Déclaration universelle des droits des peuples autochtones», in Henri Giordan (ed), Les minorités en Europe: droits linguistiques et droits de l'homme, Kimé, pp 493-507.

Françoise Morin (2005) «Les Nations Unies à l'épreuve des Peuples autochtones», in C Gros et al, Etre indien dans les Amériques aujourd'hui, Institut des Amériques.

Françoise Morin and Roberto Santana (2002) Lo transnacional, Abya Yala.

Romeo Saganash and Paul Joffe (2005) 'Indigenous Peoples and International Human Rights: Eliminating State Discrimination', Oxford Amnesty Lecture, February.

United Kingdom (Foreign and Commonwealth Office) (2004) Human Rights: Annual Report 2004, Foreign and Commonwealth Office. 